\title{
Suffer, little children: Paying the price of 'free' higher education
}

That the $75.1 \%$ pass rate for Grade 12 learners in 2017 is a fiction (real 'fake news') is common knowledge. About half of the learners who enter Grade 1 never make it to Grade 12 - the loss between Grades 10 and 12 alone is around $41 \%$, making the real pass mark closer to $37 \%$ than to $75 \%$. Equally well known are South African schools' poor performances in reading and in mathematics and science, while significant numbers of young people learn in mud, wood, zinc or asbestos schools. Open pit latrines are not unknown.

These reminders are a prelude to concerning data set out in the South African National Treasury's Estimates of National Expenditure 2018. ${ }^{1}$ But before turning to Treasury, it is worth noting that both Treasury and the Department of Higher Education and Training (DHET) have very recently been at pains to remind universities that 'free' higher education will be implemented for the approved category of students. Treasury noted that, although the funding details are still under consideration, the plan will go ahead, while DHET reminded education leaders that universities and TVET colleges must not deviate from their approved enrolment plans. Costs to the state of 'free' education in 2018 are estimated to be about ZAR15-17 billion, growing to an estimated ZAR40 billion within 3 years as the funding is extended into students' second and third years of study.

It is not clear just how the newly necessary allocation of funds over the next 3 years (presently set at ZAR57 billion) will affect other aspects of public funding for the Higher Education and Training sector. What is clear from the Estimates of National Expenditure 2018, however, is that part of the needed funding, amounting to almost ZAR11 billion, will come from reductions in the budget for Basic Education.

The largest portion of the 'savings' will come from various aspects of Infrastructure Funding; the originally budgeted sum of ZAR42.6 billion will be reduced by ZAR10.9 billion to ZAR31.7 billion - slightly more than a $25 \%$ cut. Treasury's view is that these reductions will collectively result in 'delays in completing outstanding projects' $1(0.265)$. These reductions will also mean that many rural learners will continue to go to school in mud classrooms.

The second budget reduction is in the area of Improving Matric Completion Rates and is focused specifically on the Second Chance Programme. Here, the budget of ZAR261 million is reduced by ZAR117 million (45\%) which is expected to result in 'slower expansion of the programme [in] all priority subject areas [including mathematics and science] and districts' $1(0.266)$. Interestingly, by focusing on the Second Chance Programme, improving matric completion rates does not begin to address the problem of learners who do not ever reach Grade 12.

In the Curriculum Implementation and Monitoring sub-programme, which aims to address South Africa's poor international performances in reading and in mathematics and science, the budget of ZAR1.2 billion will be reduced by ZAR50.5 million (a modest 4\%), while bursaries intended to improve the supply of qualified teachers in mathematics, science and technology will not be reduced, but will progressively result in a reduction of some 2500 bursaries (about 18\%) in each of the next two budgetary periods.

There are three reasons why reductions in parts of the budget for Basic Education are unacceptable - in fact, counterproductive. The first is that, based on performance and conditions in the sector, there is clearly a need for additional, rather than fewer, funds - and for better schools and improved management and teaching. That funding is being reduced to help cover the costs of an ill-conceived decision regarding Higher Education makes no sense at all. It simply reduces the chances of young people in the school system ever entering a university as they will not reach or pass Grade 12. As Sean Mfundza Muller, an economist at the University of Johannesburg, explains:

When the Fees Must Fall movement emerged, it
insisted its fundamental demands were based on
concern for poor South Africans. The movement
argued that this group was effectively excluded
from higher education or disadvantaged in their
studies because they could not afford the fees
and other costs of studying. The idea that the
movement for free higher education is based on
a concern for poor youth is clearly absurd when
you consider that only $5 \%$ of South Africans aged
between 15 and 34 are students in universities,
while $34 \%$ are unemployed.

The second reason why reducing the Basic Education budget to help pay for Higher Education makes no sense is that it effectively means that more tax payers will pay for Higher Education while Basic Education continues to be woefully inadequate and will serve to increase inequality rather than reduce it. According to Sean Archer from the University of Cape Town:

There are persuasive arguments that free higher education will be unambiguously regressive. This is because it involves a transfer of resources from lower to higher income individuals within a national population. ${ }^{3}$

Or, as some have put it, 'free' Higher Education implies that taxi drivers (amongst others) must help to pay to educate lawyers.

Finally (and this has reference to Dr Muller's point quoted above), there are almost twice as many young people in the 18 to 25 age group who are not in employment, education or training as there are in universities and TVET colleges. Almost none of them receives a social grant, and many live on the streets. There are no state funds available to help this population.

Weakening the Basic Education system rather than strengthening it, is, itself, an intrinsically regressive step that puts more young people at risk.

\section{References}

1. South African National Treasury. Estimates of National Expenditure 2018. Pretoria: National Treasury; 2018. Available from: http://www.treasury.gov. za/documents/national\%20budget/2018/ene/FullENE.pdf

2. Mfundza Muller S. Free higher education in South Africa: Cutting through the lies and statistics. Mail \& Guardian. 2018 January 25;Education. https:// mg.co.za/article/2018-01-25-free-higher-education-in-south-africa-cuttingthrough-the-lies-and-statistics

3. Archer S. The case against free higher education: Why it is neither just nor ethical. The Conversation. 2018 February 27;Education. Available from: https://theconversation.com/the-case-against-free-higher-education-why-itis-neither-just-nor-ethical-92193 